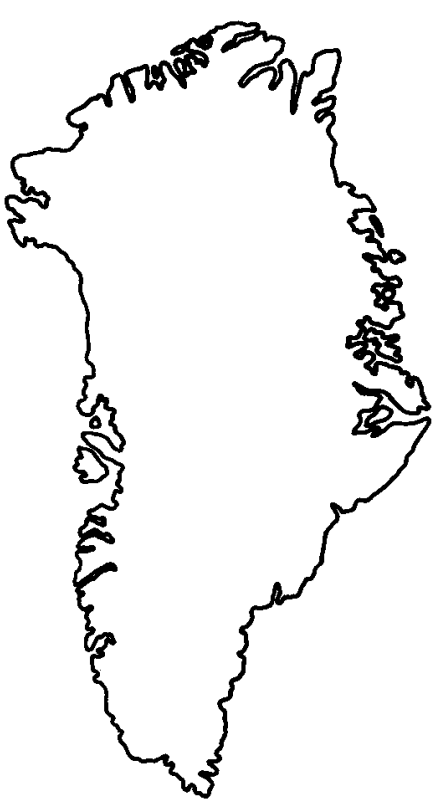

\title{
Ceratopea (Gastropoda) from Washington Land, western North Greenland
}

\author{
John S. Peel and Ellis L. Yochelson
}

\begin{abstract}
Ceratopea unguis is described from the Nunatami Formation of Washington Land, western North Greenland, confirming a late Canadian (late Early Ordovician) age. A correlation is thus established between the Nunatami Formation and the Wandel Valley Formation of Peary Land, eastern North Greenland, which also yields $C$. unguis.
\end{abstract}

J.S.P. Grønlands Geologiske Undersøgelse, Øster Voldgade 10, DK-1350 København K, Danmark.

E.L.Y. U.S. Geological Survey, E-317 U.S. National Museum of Natural History, Washington D.C. 20560, U.S.A.

During the 1976 field season in western North Greenland, Peel collected abundant specimens of Ceratopea from the Nunatami Formation at Nygaard Bugt, Washington Land (fig. 1). This is the third locality in Greenland for the Early Ordovician gastropod, which is best known from its claw-like operculum. Troelsen (1949) reported Ceratopea from the Wandel Valley Formation of Peary Land, eastern North Greenland (fig. 1), his material being subsequently described by Yochelson \& Peel (1975). Yochelson (1964) also described Ceratopea from the Narwhale Sound Formation of Ella $\varnothing$, northern East Greenland (fig. 1). The Washington Land specimens are identified as Ceratopea unguis Yochelson \& Bridge, 1958 and the record of this species is particularly significant in establishing a correlation between the Nunatami Formation and the Wandel Valley Formation, almost $600 \mathrm{~km}$ to the east, and to outcrops in the U.S.A.

\section{Occurrence of Ceratopea}

Large numbers of Ceratopea opercula were found on bedding plane surfaces of the Nunatami Formation in a measured section located about $2.5 \mathrm{~km}$ north-west of the head of Nygaard Bugt (fig. 1). Poorly preserved, specifically indeterminate specimens (GGU sample 206339) were collected at about $88 \mathrm{~m}$ above the base of the formation, in association with abundant high spired gastropods. The silicified opercula of Ceratopea unguis, described below, were collected $122 \mathrm{~m}$ above the base of the Nunatami Formation in association with a rich, but not silicified fauna of gastropods, brachiopods and trilobites (GGU sample 206346). The latter collection is from a grey, nodular limestone and associated intraformational conglomerates. The silicified opercula were freed from adherent limestone in the laboratory, with dilute hydrochloric acid. 


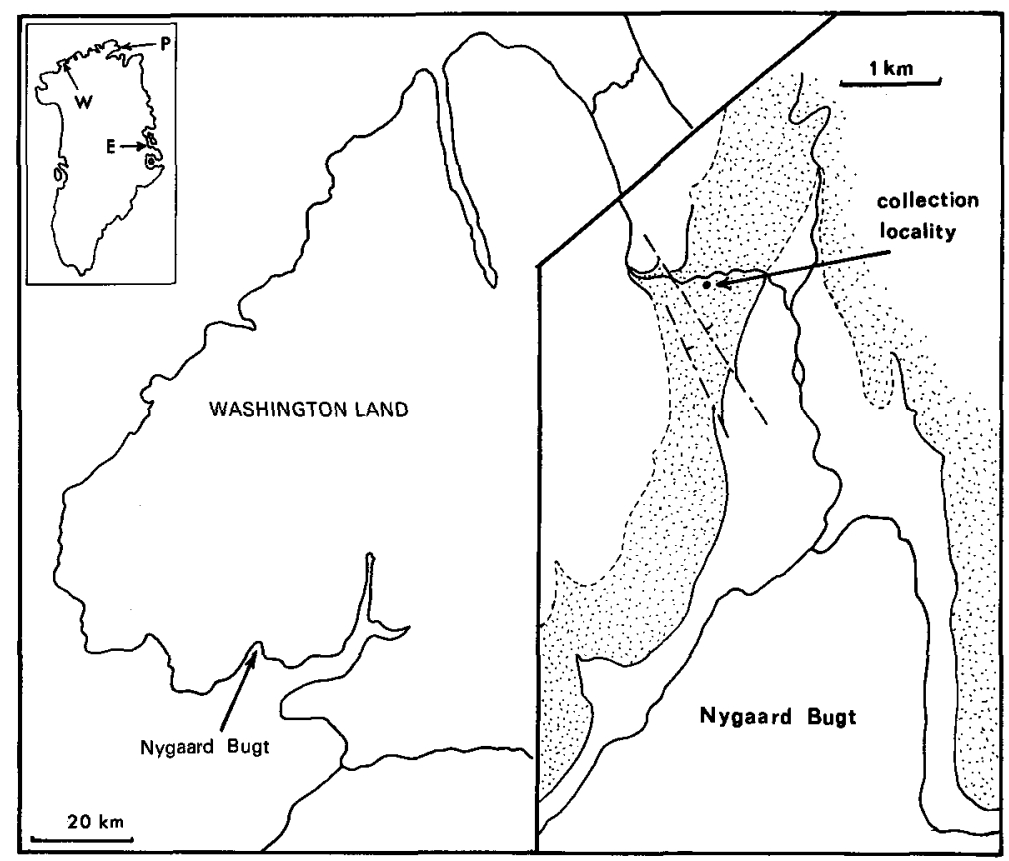

Fig. 1. Locality map, Nygaard Bugt, southern Washington Land. The outcrop of the Nunatami Formation is stippled. The small inset map of Greenland shows the position of Washington Land (W), Peary Land (P) and Ella $\varnothing(E)$.

The Nunatami Formation (c. $160 \mathrm{~m}$ ) is principally composed of grey weathering, laminated to thin bedded, silty, limestones and dolomitic limestones, which may be nodular and rubbly weathering or more massive. Pockets and thin beds of intraformational conglomerate of similar limestone occur throughout the sequence. Scattered cherts were noted at about $50 \mathrm{~m}$ above the base, and become more widespread in the interval 115-130 m. Poor silification was noted at a number of horizons in the upper half of the formation.

The Nunatami Formation contains an abundant fauna of invertebrates fully described by Poulsen (1927). Fossils appear to be mainly concentrated in the many intraformational conglomerates. With the exception of Ceratopea, few of the common species seem to have escaped the attention of Lauge Koch, who collected the specimens described by Poulsen. A new, rare, echinoderm is described by Jobson \& Paul (this report).

\section{Systematics}

The opercula from GGU sample 206346 are identified as Ceratopea unguis Yochelson \& Bridge, 1958 on the basis of comparison with the type specimens and, particularly, with large collections from the Smithville Formation of Arkansas. C. unguis is a variable species, containing both wide and narrow forms. The collection from Washington Land exhibits both, whereas that from the Wandel Valley Formation of Peary Land contained predominantly narrow forms (Yochelson \& Peel, 1975). Representative specimens are shown in fig. 2. 


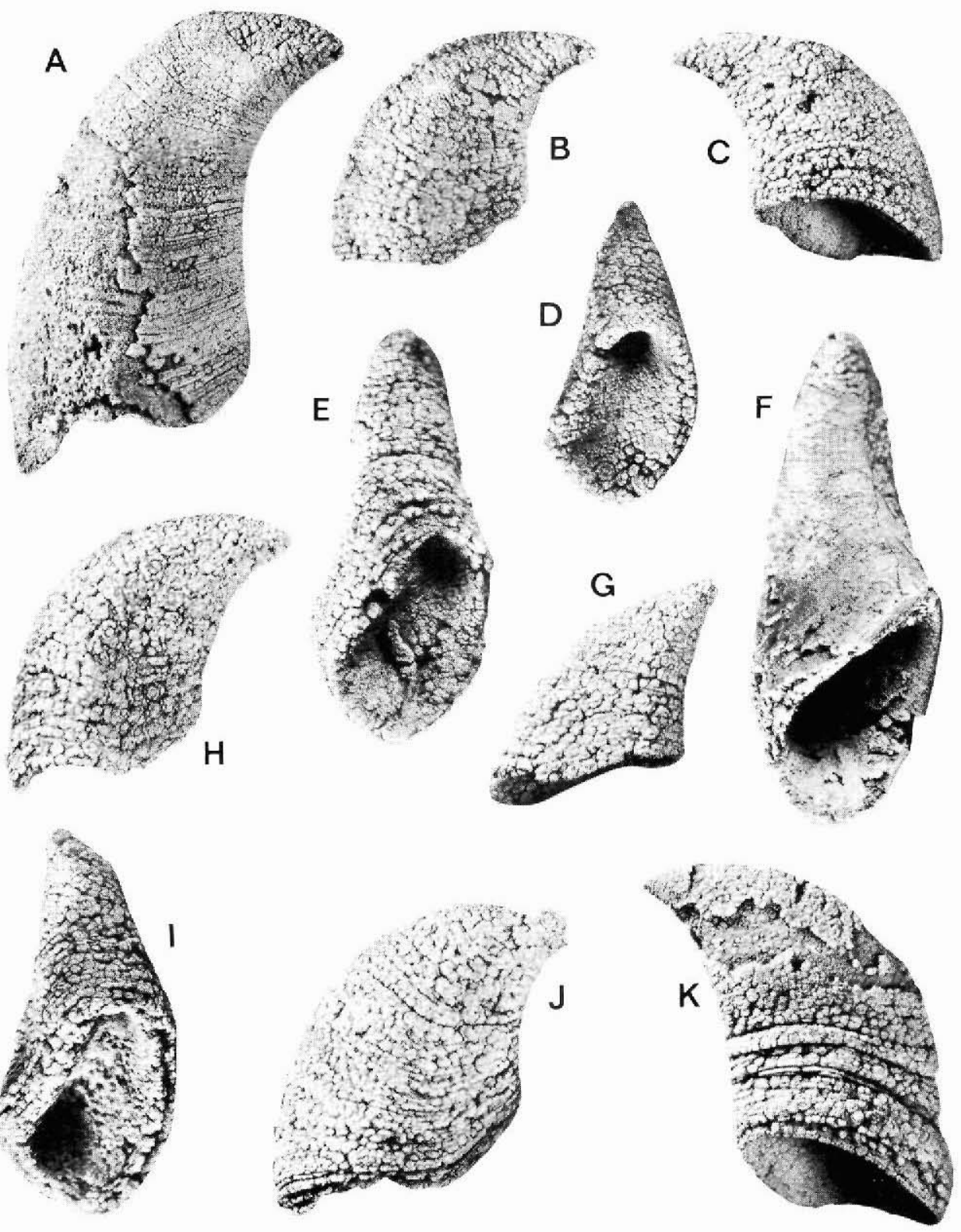

Fig. 2. Ceratopea unguis Yochelson \& Bridge, 1958, Nunatami Formation, Nygaard Bugt, Washington Land. All specimens are from GGU sample 206346 and were coated with ammonium chloride sublimate prior to photography, $\times 2$.

A, F, MGUH 14256; B, C, MGUH 14257; D, G, MGUH 14258; E, MGUH 14259; H, MGUH 14260; I, J, MGUH 14261; K, MGUH 14262.

Note the imperfect silicification in $\mathrm{A}$ and $\mathrm{K}$, and the effects of solution and abrasion at the apex in $\mathrm{E}$ and around the margins of the basal cavity in I. 
Most of the 36 specimens are complete or nearly so, although about half show the effects of solution and/or abrasion. Specimens range in length from about $10 \mathrm{~mm}$ to $28 \mathrm{~mm}$ for complete individuals, with intermediate size ranges seemingly uniformly represented.

In addition to variation in width and length, the available sample shows some differences in the nature of the attachment surface. Most specimens show the typical deep cup shape. In a few, a slightly deeper pit is present below the notch on the ventral margin of the attachment surface. Some variation is also present in the relative depth of the attachment surface. Specimens with a relatively shallow basal excavation often have thickened margins to the cavity. We ascribe this apparent thickening of the margins, and the rounding and shortening of the apex, to the effects of solution and abrasion.

Poulsen (1927) described Raphistomina latiumbilicata sp.nov. from the Nunatami Formation at Kap Webster, about $15 \mathrm{~km}$ south-west of the present Ceratopea locality. Similar lenticular gastropod shells are associated with the Ceratopea opercula, but we are unable to say at this time if these are conspecific with Poulsen's species. We consider it quite possible that the opercula known as C. unguis belong to the same species as the gastropod shells referred to Raphistomina, although we have not recorded an association of the type described by Yochelson \& Wise (1972). Until the matter is satisfactorily resolved, however, we prefer to employ the species name based on the operculum and postpone discussion of the nomenclatorial problems until a future date.

\section{Correlation}

In continental North America, Ceratopea unguis is the youngest known species of the genus and occurs in rocks of late Canadian (late Early Ordovician) age. The species is extremely abundant in the Smithville Formation of Arkansas (Wise, Yochelson \& Clardy, 1975) and also occurs in the West Spring Creek Formation of Oklahoma, the type locality (Yochelson \& Bridge, 1958). C. unguis is uncommon in the Appalachian region, although it has been found in Maryland and in the Providence Dolomite of eastern New York State (Yochelson \& Barnett, 1972). In all these areas, and also in the Nunatami Formation, study of the other fossils associated with $C$. unguis has independently indicated a late Canadian age. We are thus confident of our correlation between horizons with $C$. unguis in the Nunatami Formation and the middle member of the Wandel Valley Formation in the Borglum Elv region of Peary Land (Christie \& Peel, 1977).

It is probable that the lower member of the Wandel Valley Formation in this area, and lower beds of the middle member, which yield the slightly older species $C$. ankylosa Cullison, 1944 can be correlated with lower beds of the Nunatami Formation and the underlying Canyon Elv Formation (formerly the Cape Weber Formation of Washington Land, renamed by Peel \& Cowie, this report). The upper member of the Wandel Valley Formation is tentatively correlated with the Cape Webster Formation which overlies the Nunatami Formation in Washington Land.

Acknowledgement. Yochelson publishes with the permission of the Director, U.S. Geological Survey. 


\section{References}

Christie, R.L. \& Peel, J.S. 1977: Cambrian-Silurian stratigraphy of Børglum Elv, Peary Land, eastern North Greenland. Rapp. Grenlands geol. Unders. 82, 48 pp.

Poulsen, C. 1927: The Cambrian, Ozarkian and Canadian Faunas of northwest Greenland. Meddr Grønland 70(2), 233-343.

Troelsen, J.C. 1949: Contributions to the geology of the area round Jørgen Brønlunds Fjord, Peary Land, North Greenland. Meddr Grønland 149(2), $29 \mathrm{pp.}$

Wise, O.A. Jr., Yochelson, E.L. \& Clardy, B.F. 1975: Lower Ordovician stratigraphic relationships at Smithville, Arkansas and adjacent areas. Contributions to geology of the Arkansas Ozarks Arkansas geol. Commission, 38-60.

Yochelson, E.L. 1964: The early Ordovician gastropod Ceratopea from East Greenland. Meddr Grønland 164(7), 12 pp.

Yochelson, E.L. \& Barnett, S.J. 1972: The Early Ordovician gastropod Ceratopea in the Plattsburgh, New York area. J. Paleont. 46, 685-687.

Yochelson, E.L. \& Bridge, J. 1958: The Lower Ordovician gastropod Ceratopea. Prof. Pap. U.S. geol. Surv. 294-H, 281-302.

Yochelson, E.L. \& Peel, J.S. 1975: Ceratopea and the correlation of the Wandel Valley Formation, eastern North Greenland. Rapp. Grønlands geol. Unders. 75, 28-31.

Yochelson, E.L. \& Wise, O.A., Jr. 1972: A life association of shell and operculum in the Early Ordovician gastropod Ceratopea unguis. J. Paleont. 46, 681-684. 